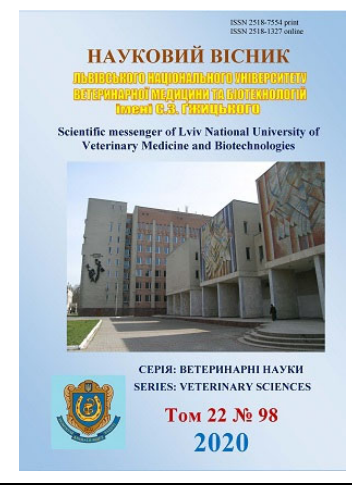

\author{
Науковий вісник Дьвівського національного університету \\ ветеринарної медицини та біотехнологій імені С.3. Гжицького. \\ Серія: Ветеринарні науки \\ Scientific Messenger of Lviv National University \\ of Veterinary Medicine and Biotechnologies. \\ Series: Veterinary sciences
}

\title{
Hoof deformity and its influence on the occurrence of chronic aseptic pododermatitis in cows
}

\author{
N. M. Khomyn ${ }^{1}$, A. R. Mysak ${ }^{1}$, S. V. Tsisinska ${ }^{1}$, V. V. Pritsak ${ }^{1}$, N. V. Nazaruk ${ }^{1}$, Yu. M. Lenjo ${ }^{1}$, \\ M. M. Khomyn ${ }^{2}$ \\ ${ }^{1}$ Stepan Gzhytskyi National University of Veterinary Medicine and Biotechnologies Lviv, Ukraine \\ ${ }^{2}$ Institute of Animal Biology NAAS, Lviv, Ukraine
}

\section{Article info}

Received 18.03.2020

Received in revised form 21.04.2020 Accepted 22.04.2020

Stepan Gzhytskyi National University of Veterinary Medicine and Biotechnologies Lviv, Pekarska Str., 50, Lviv, 79010, Ukraine.

Tel.: +38-067-894-17-12

E-mail:nadiakhomyn@ukr.net

Institute of Animal Biology of NAAS, Stusa Str., 38, Lviv, 79000, Ukraine.

\begin{abstract}
Khomyn, N. M., Mysak, A. R., Tsisinska, S. V., Pritsak, V. V., Nazaruk, N. V., Lenjo, Yu. M., \& Khomyn, M. M. (2020). Hoof deformity and its influence on the occurrence of chronic aseptic pododermatitis in cows. Scientific Messenger of Lviv National University of Veterinary Medicine and Biotechnologies. Series: Veterinary sciences, 22(98), 51-56. doi: 10.32718/nvlvet9809

It is known that deformity of the hooves is one of the most common lesions, the main cause of which is a violation of the relationship between the speed of regrowth and abrasion of the hoof horn. It develops gradually and initially does not cause changes in the organism of cows, but later leads to various diseases, including orthopedic. It is determined that in alimentary osteodystrophy (results of multifactorial mass-volume analysis and prolonged osteotendinitis of the finger flexors) and irregular corrective cleaning of the hooves and formed triggered deformation of the hooves, which leads to a violation of the support-force interactions contributes to the emergence and development of aseptic subdermatitis of chronic genesis, which is clinically appeared by lameness animals addiction, careful stepping from limb to limb, fatigue, shortening of step, etc. Simultaneously, there are changes from a bone tissue. Thus, in the area of the sole of the hoof bone, single or multiple osteophytes and exostoses are formed, which are formed in the process of ossification and metabolic disorders. According to chronic aseptic pododermatitis in cows there is a deterioration in the quality of the hoof horn, as indicated by the results of biochemical and biophysical searches. In particular, there is a decrease in calcium, sulfur, an increase in the concentration of SH-groups, a decrease in the concentration of copper, zinc, cobalt, which leads to a decrease in the density and hardness of the hoof horn, as well as an increase in abrasion resistance and a decrease in the intensity of abrasion of the horn of the animal sole, which leads to an accruing in the horn of the sole and dysfunction of the musculoskeletal system.
\end{abstract}

Key words: cows, hoof epidermis, hoof skin base, chronic aseptic pododermatitis, deformation, feeding, keeping, hoof cleaning, biochemical indices, biophysical parameters.

\section{Деформація копитець та іï вплив на виникнення асептичного пододерматиту хронічного генезу у корів}

\author{
Н. М. Хомин ${ }^{1}$, А. Р. Мисак ${ }^{1}$, С. В. Цісінська ${ }^{1}$, В. В. Прицак ${ }^{1}$, Н. В. Назарук ${ }^{1}$, Ю. М. Леньо ${ }^{1}$, \\ М. М. Хомин ${ }^{2}$ \\ ${ }^{1}$ Львівський національний університет ветеринарної медицини та біотехнологій імені С. 3. Гжиџького, \\ м. Львів, Україна \\ ${ }^{2}$ Інститут біології тварин НААН, м. Львів, Україна
}

Відомо, шуо деформація копитецьь - одне з найбільш поширених уражень, основною причиною якого є порушення співвідношення між швидкістю відростання та стирання копитцевого рогу. Вона розвивається поступово і спочатку не викликає змін з боку організму корів, але згодом призводить до виникнення різноманітних хвороб, зокрема ортопедичних. Встановлено, цьо за алімен- 
тарної остеодистрофї (результати багатофакторного мас-об'ємного аналізу і пролонгуючого остеотендиніту згиначів пальия) та нерегулярної коректуючої розчистки копитещь утворена запушена деформація копитець, щуо призводить до порушення опорносилових взаємодій, сприяє виникненню і розвитку асептичного пододерматиту хронічного генезу, шо клінічно проявляється кульгавістю, залежуванням тварин, обережним переступанням з кінцівки на кінцівку, втомою, вкороченням кроку тощо. За цих умов мають місие зміни з боку кісткової тканини. Так, у діляниі підошви копитцевої кістки виявляють поодинокі або множинні остеофіти і екзостози, щчо утворються в процесі оссифікації та порушення обміну речовин. За хронічного асептичного пододерматиту в корів спостерігається погіршення якості копитцевого рогу, на шзо вказують результати біохімічних та біофізичних досліджень. Зокрема, спостерігається зниження вмісту Кальцію, Сульфуру, підвищення конщентращії SН-груп, зниження концентрацї Купруму, Цинку, Кобальту, зниження щільності та твердості копитцевого рогу, а також збільшення опору до стирання та зниження інтенсивності стирання рогу підошви тварин, щуо призводить до наростання рогу підошви та порушення функиії опорно-рухового anapama.

Ключові слова: корови, епідерміс копитець, основа шкіри копитеиьь, хронічний асептичний пододерматит, деформація, годівля, утримання, розчистка копитець, біохімічні показники, біофізичні параметри.

\section{Вступ}

Відомо, що в умовах зимово-стійлового періоду утримання корів хвороби копитець, зокрема асептичні пододерматити, вважаються одними 3 найпоширеніших захворювань. Основними етіологічними факторами запалення основи шкіри копитець $є$ похибки в утриманні тварин, низький рівень годівлі, відсутність активного моціону, інсоляції, що призводить до погіршення якості копитцевого рогу, яка визначається окремими біохімічнити показниками та біофізичними параметрами рогу копитець. Зокрема, за погіршення умов утримання у копитцевому розі зменшується кількість вологи, збільшується концентрація SH-груп за зменшення умісту Кальцію, Сульфуру, Купруму та Цинку, знижується щільність копитцевого рогу та опір до стирання епідермісу копитець, а також підвищується інтенсивність його стирання, що сприяє зменшенню наростання епідермісу підошви (Vardanyan, 1991; Khomyn et al., 2017; Khomyn et al., 2019).

Разом 3 тим низький рівень годівлі та незбалансованість кормів раціонів спричиняють виникнення аліментарної остеодистрофії, що підтверджується, зокрема, результатами багатофакторного масоб'ємного аналізу стану кістяка (Borysevych, 2000) та величиною кутів суглобів пальців. Згідно з результатами досліджень, такі зміни призводять до розвитку дистрофічного остеотендиніту (-десмоїдиту) розгиначів пальців i, як наслідок, порушення рівномірного розподілу навантаження на підошву, виникнення деформації та порушенню постави кінцівок. Крім того, за остеодистрофії у копитцевому розі корів спостерігаєтся підвищення вмісту вологи і SH-груп та зниження концентрації Кальцію, Сульфуру, а також $\gamma$-кератоз, що впливає на біофізичні властивості епідермісу копитець, які проявляються зменшенням щільності та підвищенням опору до стирання, тобто погіршенням якості копитцевого рогу, надмірним наростанням рогу підошви, деформацією копитець, порушенням постави та розвитком асептичного пододерматиту (Lukyanovskij, 1992; Khomyn et al., 2019).

Тривалий клінічний контроль за такими тваринами дозволив встановити, що тільки у 15 \% випадків асептичні пододерматити проходять безслідно. Така патологія $є$ пусковим механізмом для розвитку важчих захворювань, особливо у тих випадках, коли причинний фактор діє тривалий період. Згідно з даними ряду авторів, у 85 \% асептичні пододерматити ускладню- ються гнійними запаленнями основи шкіри копитець, флегмонозними, виразковими, гнійно-некротичними процесами у ділянці пальців і копитець (Borysevych, 2000; Belushkina \& Severin, 2003). Тому своєчасне виявлення, а особливо запобігання розвитку запального процесу в основі шкіри копитець є актуальним.

У зв'язку з цим метою роботи є вивчення впливу нерегулярної коректувальної розчистки копитець на тлі остеодистрофії на порушення опорно-силових взаємодій копитець, виникнення деформації та розвитку хронічного асептичного пододерматиту в корів.

\section{Матеріал і методи досліджень}

Дослідження проводили у господарствах Львівської області на коровах чорно-рябої породи в зимовостійловий період за прив'язного утримання тварин. Сформували 2 групи корів (контрольна і дослідна) по 5 тварин у кожній, підібраних за принципом аналогів щодо віку, маси тіла, продуктивності. У клінічно здорових тварин (контрольна група), яким згодовували корми господарського раціону, збережена вісь пальцевих кісток, а у корів, хворих на хронічний асептичний пододерматит (дослідна група), яким згодовували корми раціону, незбалансованого та дефіцитного за поживними та мінеральними речовинами, спостерігалось порушення осі пальцевих кісток. Проведені клінічні та рентгенологічні дослідження тварин. Стан кінцівок оцінювали шляхом огляду, пальпації та вимірювання кутів суглобів суглобовим кутоміром. Стан кістяка тварин оцінювали, зокрема, шляхом проведення трепанобіопсії кісткової тканини за В. Б. Борисевичем (Borysevych, 2000). Визначення вмісту в копитцевому розі Кальцію, Фосфору, Сульфуру, Купруму, Цинку, Кобальту, концентрації SHгруп, а також щільності, твердості, опору до стирання епідермісу, інтенсивності росту і стирання підошви копитець проводили згідно із загальноприйнятими методиками.

Отримані числові дані обробляли за допомогою стандартного пакету статистичних програм Microsoft EXCEL.

\section{Результати та їх обговорення}

Дослідженнями встановлено, що корови дослідної групи неохоче, нерідко зі стогоном, піднімаються. У стані спокою часто переступають з кінцівки на кінці- 
вку. У деяких тварин за тривалого стояння спостерігається деяка напруженість пози. Корови стоять згорбленими, підводять тазові кінцівки під тулуб вбо відводять їх назад, обережно опираючись на копитця, 3 боку яких спостерігаєтьтся деформація, яка, безперечно, обумовлює порушення рівномірного розподілу навантаження на площу підошви під час опирання та спричиняє формування спотворених копитець.

У зв'язку з деформацією рельєф підошви має свої особливості, зокрема під час опирання тварини вага тіла припадає лише на незначну частину площі, тимчасом як більша частина підошви не торкається грунту. При цьому порушується рівномірний розподіл ваги тіла на площу підошви, тобто є перевантаження

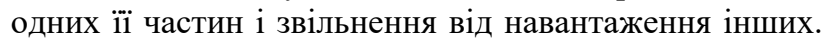
Надмірне навантаження, тобто перевантаження окремих частин підошви, відбувається тривалий період часу і приводить до глибоких функціональних змін та виникнення хронічного асептичного пододерматиту, утворення спотворених копитець і з боку копитцевого рогу проявляються дистрофією кератиноцитів, вираженим дискератозом, посиленим апоптозом, інтерцелюлярним глікопротеїнозом гематогенного та гістіогенного походження, а в основі шкіри копитець запаленням, просякненням iї глікопротеїдами плазми крові, мукоїдним набуханням, фібриноїдним набуханням, накопиченням глікопротеїдів тканинного і гематогенного походження, вираженим склерозом (Khomyn, 2006). Локомоторні особливості тазових кінцівок, а також те, що їх копитця мають відносно невеликий кут зачепа, обумовлюють частіше їх деформування.

Процес деформації, який виникає на тлі остеодистрофії, ускладнюється ще й відсутністю регулярної коректуючої розчистки копитець.

Як показали результати досліджень, за відсутності останньої на тлі аліментарної остеодистрофії спостерігається порушення постави кінцівок, здебільшого тазових, які насамперед пов'язані з надмірним прогинанням суглобів та наявністю хронічного асептичного пододерматиту (рис. 1).

Так, зменшення величини кутів путового, вінцевого та копитцевого суглобів відповідно на 58,3, 47,4 та $34,1 \%$, що становить вірогідно $107,7^{\circ} \pm 10,26,112,3^{\circ} \pm$ $9,48,18,9^{\circ} \pm 8,46$ зумовлене подовженням сухожилків i зв'язок у ділянках прикріплення їх до кісток, що контролююють у стані натягу суглобові кути, які зазнають гіперестензії.

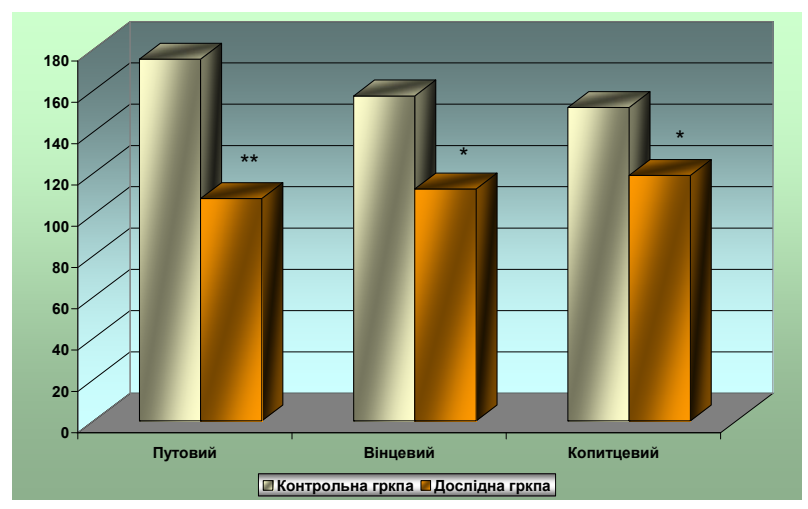

Рис. 1. Величина кутів пальцевих суглобів у корів за хронічного асептичного пододерматиту, $\mathrm{n}=5$

Такий патологічний стан визначається як дистрофічний остеотендиніт (-десмоїдит), який у всіх без винятку випадках супроводжується порушенням опорно-силових взаємодій та ураженням копитець. Окремі волокна сухожилків відриваються, а решта - витягуються; внаслідок розростання сполучної тканини у місці відриву сухожилок у цілому подовжується.

Надмірне прогинання при цьому пальцевих суглобів супроводжується зменшенням опорного навантаження на копитцеві стінки та посиленням навантаження на м'якуші. Перманентне надмірне стиснення м'якушів у стані спокою супроводжується значним механічним подразненням основи шкіри і виникненням хронічного асептичного пододерматиту, який неминуче ускладнює копитцеву деформацію. Хворі корови кульгають, багато зусиль витрачається на розчищення деформованих копитець, але виправити паталогічні копитця повністю не вдається, оскільки в них розвиваються незворотні зміни не тільки в копитцях, а й у кістковій тканині.

Підтвердженням цього є результати проведеного багатофакторного мас-об'ємного аналізу 3 метою вивчення стану кістяка (табл. 1).

\section{Таблиця 1}

Показники трепанобіоптатів кістяка корів за хронічного асептичного пододерматита, $\mathrm{M} \pm \mathrm{m}, \mathrm{n}=5$

\begin{tabular}{|c|c|c|}
\hline \multirow{2}{*}{ Показники } & \multicolumn{2}{|c|}{ Групи } \\
\hline & контрольна & дослідна \\
\hline Щільність нативної сирої кістки, мг/см ${ }^{3}$ & $1110,2 \pm 46,27$ & $646,1 \pm 39,26^{* * *}$ \\
\hline $\begin{array}{l}\text { Щільність сухої знежиреної кістки, мг/см³ } \\
\text { нативної сирої кістки }\end{array}$ & $384,6 \pm 16,57$ & $267,7 \pm 19,26^{* * *}$ \\
\hline 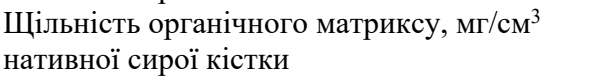 & $123,5 \pm 5,67$ & $105,3 \pm 6,03$ \\
\hline $\begin{array}{l}\text { Щільність мінеральних речовин, мг } / \mathrm{cm}^{3} \text { нати- } \\
\text { вної сирої кістки }\end{array}$ & $263,4 \pm 11,12$ & $162,5 \pm 15,79 * * *$ \\
\hline
\end{tabular}

Примітка: * - 0,05, **-P $<0,01,{ }^{* * *}-\mathrm{P}<0,001-$ у цій та подальших таблицях вірогідна різниця порівняно 3 показниками контрольної групи 
Як видно з таблиці, у корів дослідної групи статистично вірогідна різниця встановлена майже за всіма компонентами, що відображають стан кістяка. Так, щільність нативної сирої кістки у корів 3 порушенням осі пальцевих кісток та хронічним асептичним пододерматитом на 58,2 \% нижча порівняно з аналогічним показником тварин контрольної групи, щільність сухої знежиреної кістки - на 69,6 \%, щільність мінеральних речовин - на $61,7 \%$. Величина індексу мінералізації нижча на 46,0 \%, що становить 1,48 \pm 0,090.

Отже, важливим чинником, який сприяє виникненню хронічного асептичного пододерматиту в корів, є остеодистрофія. На тлі остеодистрофічних уражень виникає пролонгуючий остеотендиніт пальцевих

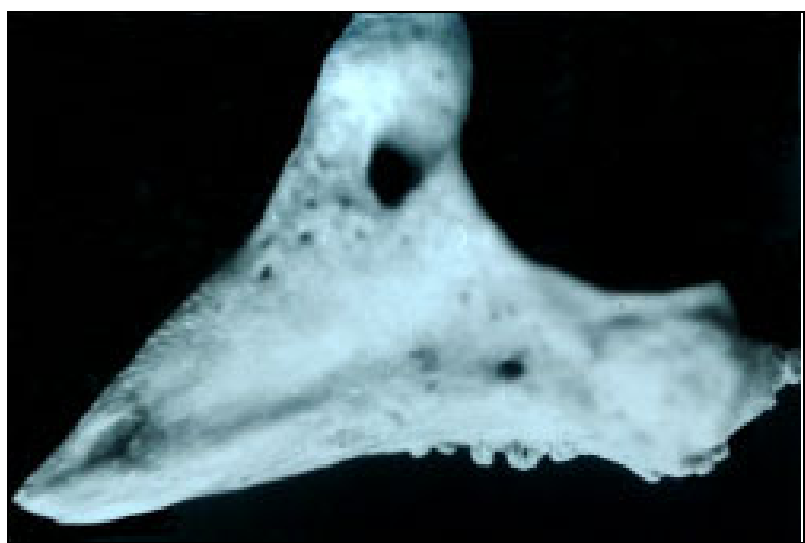

Рис. 2. Остеофіти у п’яточній частині копитцевої кістки згиначів, що призводить до перерозгинання пальців, часткового або повного виключення з опори копитцевих стінок та перевантаження м'якушів. Посилення опори на м'якуші супроводжується виникненням в основі шкіри копитець запалення хронічного характеру, викликаного тривалим надмірним перевантаженням окремих ділянок підошви, а також лонгозу сухожилків. У цих ділянках з часом розвиваються проліферативні процеси, особливо у п'яточній частині підошви та у місці прикріплення сухожилка глибокого згинача пальця до підошви копитець.

У цих місцях згодом розвиваються поодинокі або численні екзостози (рис. 2, 3).

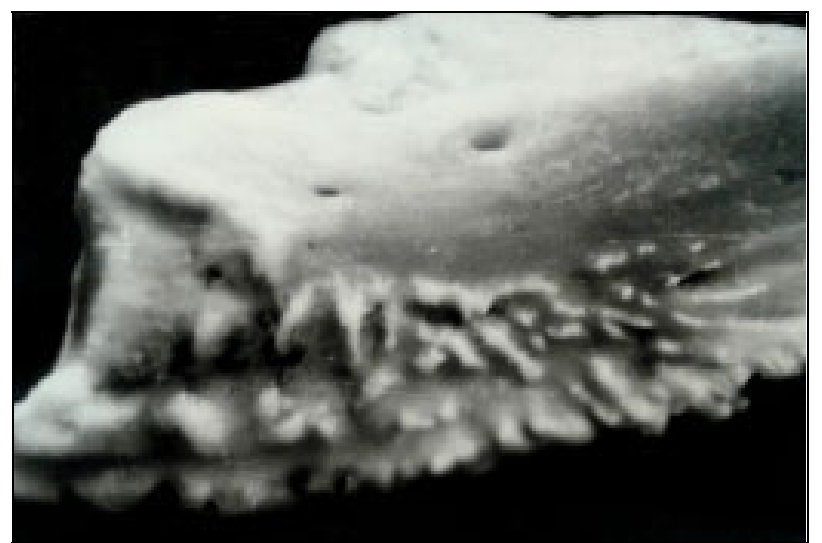

Рис. 3. Численні остеофіти на підошві копитцевої кістки

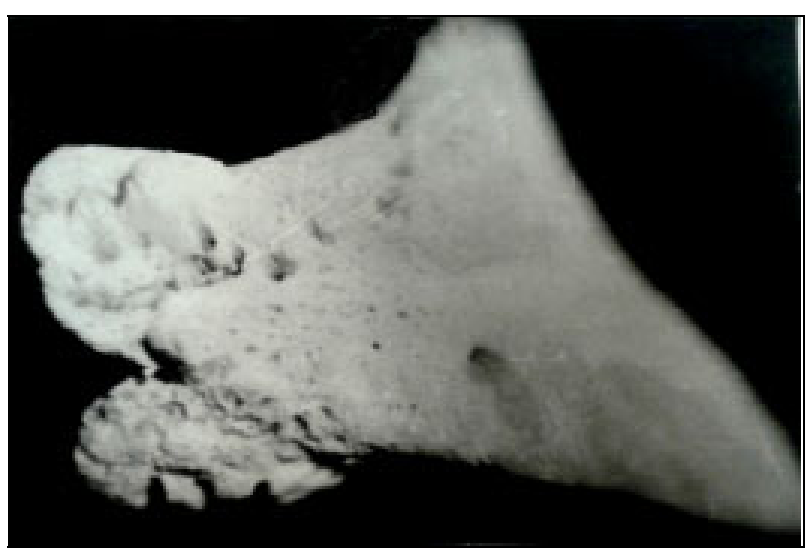

Рис. 4. Екзостоз у п’яточній частині копитцевої кістки

Такі зміни негативно впливають на функції кінцівок. Навіть за невеликих навантажень у тварин спостерігається втома, інколи з'являється кульгавість. Крок вкорочений, вони важко піднімаються, частіше залишаються в лежачому положенні. Новоутворені нарости на підошві копитець мають нерівну поверхню з явно збільшеними просвітами для судин (екзостози). Вся поверхня підошви деформується за рахунок вогнищевого розростання новоутвореної кісткової тканини (рис. 4).

Зрозуміло, що наявність таких змін обумовлює болючість за тривалого руху або у період спокою, що змушує тварин лежати. Процес ускладнюється ще й тим, що зміни відбуваються з боку епідермісу копи- тець, про що свідчать результати біохімічних досліджень копитцевого рогу корів, хворих на хронічний асептичний пододерматит.

Так, в епідермісі копитець встановлено зниження концентрації Кальцію на 15,1%. Відомо, що кальцієвий гомеостаз впливає на міцність копитцевого рогу, оскільки Кальцій, коагулюючись у матриксі епідерміса, забезпечує оптимальні біофізичні властивості копитцевого рога. Варто зазначити, що у цій частині пальця накопичується так званий лабільний Кальцій, вміст якого регулюється надходженням його з кормів раціону (табл. 2).

Окремої уваги заслуговує наявність у копитцевому розі Сульфуру, який безпосередньо бере участь у 
процесах кератинізації. Як відомо, Сульфур в організмі тварин $є$ у вигляді органічних та неорганічних сполук і входить до складу більшості білків, особливо білків покривних тканин. В організм тварин він надходить 3 кормом у вигляді органічних (білків, амінокислот, вітамінів) і неорганічних (сульфатів) сполук.

\section{Таблиця 2}

Вміст мінеральних речовин у копитцевому розі корів за хронічного асептичного пододерматиту, $\mathrm{M} \pm \mathrm{m}, \mathrm{n}=5$

\begin{tabular}{lcc}
\hline \multicolumn{1}{r}{ Показники } & & Група \\
\cline { 2 - 3 } & контрольна & дослідна \\
\hline Кальцій, г/кг & $1,86 \pm 0,057$ & $1,58 \pm 0,027^{* *}$ \\
Фосфор, г/кг & $1,18 \pm 0,029$ & $1,20 \pm 0,036$ \\
Сульфур, г/кг & $18,15 \pm 0,279$ & $15,04 \pm 0,212^{* * *}$ \\
Купрум, мг/кг & $27,84 \pm 0,625$ & $22,97 \pm 1,139^{* * *}$ \\
Цинк, мг/кг & $18,12 \pm 0,378$ & $16,25 \pm 0,357^{*}$ \\
Кобальт, мг/кг & $9,28 \pm 0,230$ & $7,81 \pm 0,195^{* *}$ \\
\hline
\end{tabular}

Дослідженнями встановлено, що в копитцевому розі тварин дослідної групи знизилась концентрація Сульфуру на 17,2 \%, що впливає на погіршення процесу кератинізації, який проявляється підвищенням концентрації сульфгідрильних груп на 39,8 \%. Збільшення величини показника до $46,8 \pm 2,35$ мкмоль/г, на нашу думку, свідчить про погіршення процесу кератинізації, тобто якості копитцевого рогу.

Зменшення концентрації Купруму в копитцевому розі на 17,5 \%, очевидно, впливає на якість епідермісу копитець завдяки iї здатності каталізувати окиснення сульфгідрильних груп прекератину в дисульфідні зв'язки кератину (стимулює процес ороговіння). Вiдомо, що Купрум сприяє зміцненню не тільки копитцевого рогу, а й дерми, завдяки ії здатності разом із лізилоксидазою та киснем брати участь у формуванні поперечних міжковалентних зв'язків у колагенових волокнах. Крім того, Купрум бере участь у синтезі гемоглобіну, прискорює мобілізацію депонованого заліза і перенесення його до кісткового мозку. Вона також активізує обмін вітамінів А і C та утворення ряду ферментів, лімітує синтез колагену й основної речовини сполучної тканини тощо.

Має місце зниження вмісту Цинку - на 10,4 \%. 3 наявністю в організмі останнього пов'язані процеси обміну речовин, особливо білкового і вуглеводного. Він своєю чергою регулююче впливає на активність розщеплення та всмоктування поживних речовин; дефіцит Цинку призводить до розвитку паракератозу, а також до порушення процесів кісткоутворення та кровотворення. Вміст Кобальту в копитцевому розі тварин нижчий на $15,8 \%$, що також свідчить про порушення обмінних процесів в організмі ортопедично хворих тварин.

Підтвердженням порушення кератинізації є вірогідне зниження щільності та твердості відповідно на 4,0 і $12,5 \%$, а також збільшення опору до стирання на $16,4 \%$ (табл. 3).

На нашу думку, такі зміни біофізичних параметрів копитцевого рогу пов'язані з дефіцитом мінеральних речовин та незавершеною кератинізацією епідермісу підошви. Внаслідок цього знижується інтенсивність стирання рогу підошви тварин дослідної групи на 33,6 , а контрольної - на $24,0 \%$, тобто наростання рогу підошви безпосередньо спричиняє виникнення деформації копитець, яке є одним 3 пускових механізмів розвитку запалення основи шкіри копитець корів хронічного генезу.

\section{Таблиця 3}

Біофізичні показники копитцевого рогу корів за хронічного асептичного пододерматиту, $\mathrm{M} \pm \mathrm{m}, \mathrm{n}=5$

\begin{tabular}{|c|c|c|}
\hline \multirow{2}{*}{ Показники } & \multicolumn{2}{|c|}{ Групи } \\
\hline & контрольна & дослідна \\
\hline 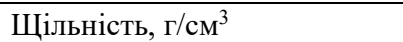 & $1,195 \pm 0,0150$ & $1,147 \pm 0,0100^{*}$ \\
\hline Твердість, кгс/см ${ }^{2}$ & $154,5 \pm 2,36$ & $135,2 \pm 1,95 * * *$ \\
\hline Опір до стирання об/мм & $98,5 \pm 4,26$ & $114,7 \pm 4,39^{*}$ \\
\hline Ріст, мм/міс. & $10,8 \pm 0,84$ & $11,3 \pm 0,36$ \\
\hline Стирання, мм/міс. & $8,2 \pm 0,19$ & $7,5 \pm 0,05^{* *}$ \\
\hline
\end{tabular}

У процесі деформації копитець, зокрема наростання епідермісу підошви, важливого значення надається апоптозу, встановленому в епідермісі копитець. Апоптоз як фізіологічне явище виконує функцію гомеостатичної регуляції оптимального об’єму тканини, а також бере участь у диференціації клітин і вважається патогенетичним механізмом багатьох хвороб (Belushkina \& Severin, 2003).

Яскраво виражені епідермальні зміни мають місце за умов виникнення запущеної деформації, що супро- воджується посиленим апоптозом, який порівняно 3 контрольним показником зростає майже десятикратно. За цих умов епідерміс втрачає ознаки клітинної будови, епідермоцити зливаються в аморфну зцементовану масу, яка перешкоджає нормальному процесу стирання епідермісу підошви, що призводить до його надмірного нашарування

Відомо, що чинниками посилення апоптозу в епідермісі копитець $є$ гіпоксія, дія ексудату на епідермоцити білків, а головне - підвищення внутрішньотка- 
нинного тиску, зокрема у зв'язку з чітко встановленим просочуванням епідермісу глікопротеїдними сполуками, які цементують змертвілі кератиноцити, порушуючи процес їх відшарування. За цих обставин збільшується об'єм рогової тканини і остання зазнає деформації.

Отже, проведене дослідження дає підстави чітко прослідкувати етіопатогенез хронічного асептичного пододерматиту в корів (рис. 5).

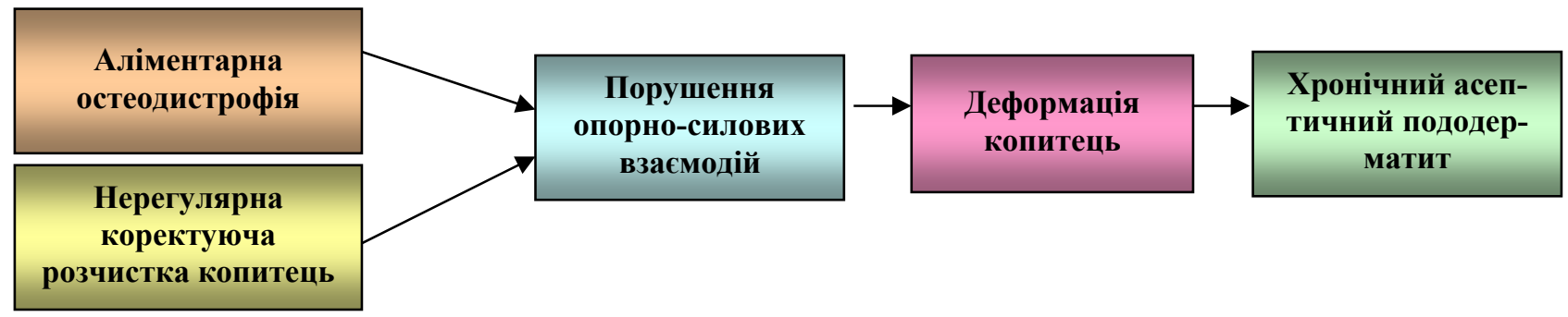

Рис. 5. Етіопатогенез хронічного асептичного пододерматиту в корів

Отже, регулярна коректуюча розчистка копитець $є$ важливим заходом впливу на них не тільки на макрорівні, а й на клітинному рівні. Раціональна корекція обов'язковий профілактично-лікувальний захід за умов ортопедичної патології, а надто при деформації копитець, яка на тлі аліментарної дистрофії, нерегулярної коректуючої розчистки, що призводить до порушення опорно-силових взаємодій, є патоморфологічним відображенням хронічного перебігу асептичного пододерматиту.

\section{Висновки}

1. Деформація копитець, яка виникає на тлі аліментарної остеодистрофії за нерегулярної коректуючої розчистки копитець і супроводжується порушенням опорно-силових взаємодій, $\epsilon$ пусковим механізмом розвитку хронічного асептичного пододерматиту.

2. За хронічного асептичного пододерматиту виникають зміни з боку кісткової тканини у вигляді екзостозів та остеофітів у ділянці підошви.

3. Асептичний пододерматит хронічного генезу супроводжується погіршенням якості копитцевого рогу, що проявляється змінами окремих біохімічних та біофізичних показників, зокрема зниженням вмісту Кальцію на 15,1 \%, Сульфуру - на 17,2 \%, підвищенням концентрації SH-груп на 39,8 \%, зниженням вмісту Купруму на 17,5, Цинку - на 10,4, а Кобальту - на 15,8 \%, що призводить до зниження щільності та твердості відповідно на 4,0 і 12,5\%, а також збільшення опору до стирання на 16,4 \%, внаслідок чого знижується інтенсивність стирання рогу підошви тварин дослідної групи на 33,6 \%, а контрольної - на 24,0 \%, тобто має місце наростання рогу підошви.

Перспективи подальших досліджень. Дослідження будуть спрямовані на розробку нових заходів профілактики хронічного асептичного пододерматиту в корів.

\section{References}

Belushkina, N. N., \& Severin, S. E. (2003). Molekulyarnye osnovy patologii apoptoza. Apoptoz v mnogokletochnom organizme. Biologiya, 68(2), 5158 (in Russian).

Borysevych, V. B. (2000). Bagatofaktornyi mas-obemnyi analiz kistkovoyi tkanyny. Visnyk agrar. nauki, 3, 3538 (in Ukrainian).

Khomyn, N. M., Mysak, A. R., Tsisinska, S. V., Pritsak, V. V., Lenyo, Yu. M., \& Khomyn, M. M. (2019). The role of osteodystrophy in the pathogenesis of aseptic pododermatitis in cows. Scientific Messenger of Lviv National University of Veterinary Medicine and Biotechnologies. Series: Veterinary sciences, 21(96), 129-133. doi: 10.32718/nvlvet9623.

Khomyn, N. M. (2006). Aseptychni pododermatyty u velikoyi rogatoyi hudobi (etiologiya, patogenez, profilaktika ta likuvannya): Avtoref. diss... d-ra vet. nauk: 16.00.05. Bila Cerkva (in Ukrainian).

Khomyn, N. M., Mysak, A. R., Tsisinska, S. V., \& Pritsak, V. V. (2017). The quality of the hoof horns of cattle and the influence of certain etiological factors. Scientific Messenger of Lviv National University of Veterinary Medicine and Biotechnologies, 19(82), 175-179. https:/nvlvet.com.ua/index.php/journal/article/view/13 60.

Khomyn, N. M., Mysak, A. R., Tsisinska, S. V., Pritsak, V. V., Lenyo, Yu. M., \& Khomyn, M. M. (2019). The influence of conditions of detention the hoof and the development of aseptic inflammation of the producing layer of the base of the skin soles hooves in the cows. Scientific Messenger of Lviv National University of Veterinary Medicine and Biotechnologies. Series: Veterinary sciences, 21(94), 179-183. doi: 10.32718/nvlvet9433.

Lukyanovskij, V.A. (1992). Vliyanie sanitarnogigienicheskih uslovij na patologiyu kopytec u korov. Veterinariya, 1, 17-20 (in Russian).

Vardanyan, A. V. (1991). Biofizicheskie i biohimicheskie pokazateli kopytcevogo roga u korov. Biologicheskie i himioterapevticheskie sredstva profilaktiki zabolevanij zhivotnyh: Trudy Erevanskogo zoovet in-ta. Erevan, 63, 65-67 (in Russian). 